\title{
Circulating levels of calcitonin gene-related peptide (CGRP) are lower in COVID-19 patients
}

Laura Ochoa-Callejero ${ }^{1}$, Josune García-Sanmartín ${ }^{1}$, Pablo Villoslada-Blanco ${ }^{2}$, María Íñiguez ${ }^{2}$, Patricia Pérez-Matute ${ }^{2}$, Rachel Brody ${ }^{3}$, José A. Oteo ${ }^{2,4}$, Alfredo Martínez ${ }^{1}$.

${ }^{1}$ Oncology Area, Center for Biomedical Research of La Rioja (CIBIR), Logroño, Spain.

${ }^{2}$ Infectious Diseases, Microbiota, and Metabolism Unit (CIBIR), Logroño, Spain.

${ }^{3}$ Department of Pathology, Icahn School of Medicine at Mount Sinai, New York, USA.

${ }^{4}$ Infectious Diseases Department. Hospital Universitario San Pedro, Logroño, Spain.

Correspondence to: Alfredo Martínez, Angiogenesis Group, Oncology Area, Center for Biomedical Research of La Rioja (CIBIR), Piqueras 98, 26006 Logroño, Spain. Phone: +34 941278775; Fax: +34 941278887; email: amartinezr@riojasalud.es

Sources of support: This study was funded by Fundación Rioja Salud.

Conflict of interests: Authors declare that no conflict of interest exists. 
medRxiv preprint doi: https://doi.org/10.1101/2020.10.01.20205088; this version posted October 2, 2020. The copyright holder for this preprint (which was not certified by peer review) is the author/funder, who has granted medRxiv a license to display the preprint in It is made available under a CC-BY-ND 4.0 International license.

Ochoa-Callejero et al. 2

\section{Abstract}

Background: To better understand the biology of COVID-19, we have explored the behavior of calcitonin gene-related peptide (CGRP), an angiogenic, vasodilating, and immune modulating peptide, in SARS-CoV-2 positive patients.

Methods: Levels of CGRP in the serum of 57 COVID-19 patients (24 asymptomatic, 23 hospitalized in the general ward, and 10 admitted to the intensive care unit) and healthy donors $(n=24)$ were measured by ELISA. In addition, to better understand the physiological consequences of the observed variations, we investigated by immunofluorescence the distribution of RAMP1, one of the components of the CGRP receptor, in autopsy lung specimens.

$\underline{\text { Results: }}$ CGRP levels greatly decreased in COVID-19 patients $(\mathrm{p}<0.001)$ when compared to controls, and there were no significant differences due to disease severity, sex, age, or comorbidities. We found that COVID-19 patients treated with proton pump inhibitors had lower levels of CGRP than other patients not taking this treatment $(\mathrm{p}=0.001)$. RAMP1 immunoreactivity was found in smooth muscle cells of large blood vessels and the bronchial tree, and in the airways epithelium. In COVID-19 samples, RAMP1 was also found in proliferating type II pneumocytes, a common finding in these patients.

Conclusions: The lower levels of CGRP should negatively impact the respiratory physiology of COVID-19 patients due to vasoconstriction, improper angiogenesis, less epithelial repair, and faulty immune response. Therefore, restoring CGRP levels in these patients may represent a novel therapeutic approach for COVID-19.

Keywords: COVID-19, CGRP, RAMP1, proton pump inhibitors, type II pneumocyte hyperplasia, airway hyperresponsiveness, ILC2. 
medRxiv preprint doi: https://doi.org/10.1101/2020.10.01.20205088; this version posted October 2, 2020. The copyright holder for this preprint (which was not certified by peer review) is the author/funder, who has granted medRxiv a license to display the preprint in It is made available under a CC-BY-ND 4.0 International license .

Ochoa-Callejero et al. $\quad 3$

\section{Introduction}

The COVID-19 pandemic has developed into the major challenge to global health in our lifetime. This disease is caused by severe acute respiratory syndrome coronavirus 2 (SARS-CoV-2) and it affects people in different ways, ranging from asymptomatic disease to severe pneumonia than may require oxygen therapy, and even leading to death ${ }^{1}$. At present there is no specific treatment for the disease and only prevention strategies such as promoting social distance, increasing general hygiene, and applying symptomatic remedies can reduce COVID-19 impact ${ }^{2}$. Also, vaccine development is progressing rapidly ${ }^{3}$. A full understanding of the biology implicated in the evolution of the disease may provide new ideas for the treatment and management of patients. In this regard, interesting data are arising from the study of autopsy specimens ${ }^{4}$. Among other pathological findings, the occurrence of angiogenesis in the lung of seriously affected patients has been reported ${ }^{5}$. A recent article has studied the potential pro-angiogenic molecules whose expression is upregulated in COVID-19 patients ${ }^{6}$. Among those markers, we were especially interested in receptor activity modifying protein 1

(RAMP1) which, in combination with the calcitonin receptor-like receptor (CLR), constitutes the receptor for calcitonin gene-related peptide (CGRP) ${ }^{7}$.

CGRP is a pro-angiogenic molecule ${ }^{8}$ but it also plays other important roles in the lung including vasoregulation, bronchoprotection, anti-inflammatory actions, and tissue repair ${ }^{9,10}$, all of them very relevant for the evolution of COVID-19 pathogenesis. In the normal lung, CGRP is found in neuroepithelial bodies and in nerve fibers which contact the epithelium, neuroendocrine cells, and smooth muscle ${ }^{11}$. CGRP binding sites have been found in pulmonary blood vessels, and the smooth muscle and epithelium of large airways ${ }^{12}$. It has been shown that CGRP promotes the growth of bronchial ${ }^{13}$ and 
medRxiv preprint doi: https://doi.org/10.1101/2020.10.01.20205088; this version posted October 2, 2020. The copyright holder for this preprint (which was not certified by peer review) is the author/funder, who has granted medRxiv a license to display the preprint in It is made available under a CC-BY-ND 4.0 International license.

Ochoa-Callejero et al. 4

alveolar ${ }^{14}$ epithelial cells following lung injury, thus acting as a protective mediator in all kinds of experimental procedures involving lung insults ${ }^{15}$.

Another important function for CGRP in the lung is the regulation of the immune system. CGRP expression is enhanced in response to inflammation ${ }^{16}$ and it exerts antiinflammatory actions by regulating macrophage polarization ${ }^{17}$ and by inhibiting dendritic and T cells ${ }^{18}$. CGRP also limits group 2 innate lymphoid cell (ILC2) responses ${ }^{19}$. Depending on the context, this anti-inflammatory potential may be positive or negative for the patient. For instance, the presence of CGRP-positive nerves reduced immunity and thus survival in a model of lethal Staphylococcus aureus pneumonia ${ }^{20}$. In addition, in knock-out models, where either the peptide ${ }^{21}$ or the receptor ${ }^{22}$ were disrupted, there was a reduction of allergic asthma responses. This involvement with the immune system could be critical for the pathophysiology of COVID-19 ${ }^{23}$.

Therefore, our objective was to evaluate the levels of circulating CGRP in COVID-19 patients with different symptoms and to compare them with healthy controls. We also studied the expression of RAMP1 in the lungs of patients who died of COVID-19 and compared them with patients who died by unrelated causes.

\section{Methods}

Serum samples. Blood samples were obtained at Hospital San Pedro (Logroño, Spain) from healthy volunteers recruited before the initiation of the pandemia $(n=24)$, and from COVID-19-positive patients (confirmed by PCR), which were subdivided in 3 groups depending on disease severity: i) asymptomatic or mildly symptomatic patients not requiring hospitalization $(\mathrm{n}=24)$, ii) patients requiring hospitalization in the normal ward 
medRxiv preprint doi: https://doi.org/10.1101/2020.10.01.20205088; this version posted October 2, 2020. The copyright holder for this preprint (which was not certified by peer review) is the author/funder, who has granted medRxiv a license to display the preprint in It is made available under a CC-BY-ND 4.0 International license.

Ochoa-Callejero et al. 5

( $n=23)$, and iii) patients admitted to the intensive care unit (ICU) $(n=10)$. Blood was collected in serum separator tubes (BD Vacutainer, Becton Dickinson, Franklin Lakes, $\mathrm{NJ}$ ) and serum was isolated, aliquotted, and frozen at $-80^{\circ} \mathrm{C}$ until further analysis. Relevant clinical data were obtained from the clinical history of the patients. All procedures were approved by the local review board (Comité de Ética de Investigación con Medicamentos de La Rioja, CEImLAR, ref. PI-412). All described procedures adhere to the tenets of the Declaration of Helsinki.

Autopsy specimens. Paraffin tissue sections from the lung of three patients who died from COVID-19 and from three other patients who died from pathologies unrelated to COVID-19, and with no lung involvement, were generated at the Department of Pathology of the Icahn School of Medicine at Mount Sinai (New York), and sent to Spain for analysis.

CGRP ELISA protocol. Levels of CGRP were quantitated in serum samples using a commercial enzyme-linked immunosorbent assay (ELISA) kit (MBS2023906, MyBioSource, San Diego, CA), following manufacturer's instructions.

Immunofluorescence and confocal microscopy. Tissue sections were dewaxed, rehydrated, and subjected to antigen retrieval (10mM Sodium Citrate, 0.5\% Tween 20, $\mathrm{pH}$ 6.0, 20 min at $95^{\circ} \mathrm{C}$ ). Non-specific binding was blocked by exposure to $10 \%$ normal donkey serum (Jackson Immunoresearch Laboratories, West Grove, PA) for 1 h, and then tissue sections were incubated with recombinant rabbit monoclonal anti-RAMP1 antibody, clone EPR10867 (ab156575, Abcam), overnight at $4^{\circ} \mathrm{C}$. The following day, sections were incubated with fluorescent secondary antibody, CF633 donkey anti-rabbit 
medRxiv preprint doi: https://doi.org/10.1101/2020.10.01.20205088; this version posted October 2, 2020. The copyright holder for this preprint (which was not certified by peer review) is the author/funder, who has granted medRxiv a license to display the preprint in It is made available under a CC-BY-ND 4.0 International license.

Ochoa-Callejero et al. 6

IgG (20125, Biotium, Fremont, CA), for 1 h. Finally, they were counterstained with DAPI (Molecular Probes, Eugene, OR) and analyzed with a confocal microscope (TCS SP5, Leica, Badalona, Spain). Negative controls were performed by substituting the primary antibody by PBS.

Statistical analysis.

All data were analyzed with GraphPad Prism 8 software and were considered statistically significant when $\mathrm{p}<0.05$. Values are expressed as means $\pm \mathrm{SEM}$. Normally distributed data were evaluated by Student's $t$ test or by ANOVA followed by the Dunnet’s post-hoc test, while data not following a normal distribution were analyzed with the Kruskal-Wallis test followed by the Mann-Whitney U test. Categorical data were analyzed with Fisher's exact test.

\section{Results}

Serum samples were collected from healthy volunteers $(n=24)$ and from PCR-confirmed COVID-19 patients ( $\mathrm{n}=57)$ whose disease had different degrees of severity: asymptomatic $(n=24)$, hospitalized in the general ward $(n=23)$, or admitted to the intensive care unit (ICU) $(n=10)$. Three of the patients in the ICU group eventually died of COVID-19 complications. Age distribution of the healthy control population was lower than that of the COVID-19 group but no differences were found in gender distribution (Table 1). As expected, patients with more serious disease were older $(\mathrm{p}<0.001)$ and had a higher number of comorbidities, including hypertension $(\mathrm{p}<0.001)$ and dyslipidemia ( $\mathrm{p}=0.02)$. They were also more likely to be taking chronic medication such as angiotensin-converting enzyme (ACE) inhibitors ( $\mathrm{p}=0.007)$, antidiuretics $(p=0.007)$, antidepressants $(p=0.007)$, or proton pump inhibitors $(p=0.008)$ (Table 2$)$. 
medRxiv preprint doi: https://doi.org/10.1101/2020.10.01.20205088; this version posted October 2, 2020. The copyright holder for this preprint (which was not certified by peer review) is the author/funder, who has granted medRxiv a license to display the preprint in It is made available under a CC-BY-ND 4.0 International license.

Ochoa-Callejero et al. 7

CGRP levels were measured in the serum of all subjects by ELISA. Healthy volunteers' CGRP levels were $289.9 \pm 35.9 \mathrm{pg} / \mathrm{ml}$, whereas COVID-19 patients presented significantly lower levels: $105.7 \pm 7.0 \mathrm{pg} / \mathrm{ml}(\mathrm{p}<0.001)$. When separated by disease severity, the three COVID-19 groups displayed significantly lower levels of CGRP when compared to healthy controls, but there were no significant differences among disease groups (Fig. 1A). No differences were found in CGRP levels by sex or age in either the healthy or the disease groups (results not shown). When testing comorbidities and chronic drug treatments, we found that patients receiving proton pump inhibitors had significantly lower levels of CGRP than the rest of COVID-19 patients $(\mathrm{p}=0.001)$ (Fig. 1B). To test whether these pump inhibitors were responsible for the total reduction in CGRP levels observed in the COVID-19 population, we reanalyzed the data after removing all patients treated with the inhibitors $(n=12)$. The remaining patients $(n=45)$ had CGRP levels of $110.2 \pm 7.6 \mathrm{pg} / \mathrm{ml}$, and were still significantly lower than the healthy control levels $(\mathrm{p}<0.001)$. All other conditions did not significantly affect CGRP levels.

In order to better understand the physiological consequences in the lung of the systemic reduction in CGRP levels, we investigated by immunofluorescence the distribution of the CGRP receptor component RAMP1. RAMP1 immunoreactivity was studied in lung sections of three patients who died from COVID-19 complications and of three other patients who died from causes unrelated to COVID-19, with no lung pathology. In the normal lung, RAMP1 immunoreactivity was predominantly found in the muscle layer surrounding large blood vessels (Fig. 2A) and major airways, and, with lower intensity, in the bronchial and bronchiolar epithelium (Fig. 2C). No RAMP1 immunoreactivity 
medRxiv preprint doi: https://doi.org/10.1101/2020.10.01.20205088; this version posted October 2, 2020. The copyright holder for this

preprint (which was not certified by peer review) is the author/funder, who has granted medRxiv a license to display the preprint in

It is made available under a CC-BY-ND 4.0 International license.

Ochoa-Callejero et al. 8

was found in the alveolar epithelium. Absence of the primary antibody completely precluded labeling, thus confirming staining specificity (Fig. 2B,D).

As previously reported ${ }^{4}$, histological analysis of the COVID-19 affected lungs revealed epithelial denudation, thromboemboli, hyaline deposits, bronchopneumonia, and proliferation of type II pneumocytes (Fig. 3B), when compared to lungs from nonCOVID-19 cases (Fig. 3A). The pattern of RAMP1 immunoreactivity in COVID-19 patients was similar to the one described in non-COVID-19 slides, labeling smooth muscle cells and airway epithelium (Fig. 3C). Remarkably, the proliferating type II pneumocytes displayed an intense immunoreactivity for RAMP1 (Fig. 3D).

\section{Discussion}

In this study we have shown that CGRP serum levels become significantly reduced in COVID-19 patients, independently of their disease severity status. In addition, we found that RAMP1 immunoreactivity was predominantly found in the walls of the main vessels and airways, and in the bronchial/bronchiolar epithelium. The hyperplastic type II pneumocytes found in COVID-19 patients were also immunoreactive for RAMP1.

A limitation of the study was that the healthy control group had a lower mean age than the COVID-19 group. This was due to the fact that we wanted to use control samples collected before the pandemia to avoid inclusion of potential asymptomatic subjects, and therefore we had no control over their specific characteristics. Levels of CGRP were not affected by either age or sex in our study, so the age difference should not influence the main conclusions of the study. In addition, the age of the control group is 
medRxiv preprint doi: https://doi.org/10.1101/2020.10.01.20205088; this version posted October 2, 2020. The copyright holder for this preprint (which was not certified by peer review) is the author/funder, who has granted medRxiv a license to display the preprint in It is made available under a CC-BY-ND 4.0 International license.

Ochoa-Callejero et al. 9

the same as our asymptomatic population, and the CGRP differences between them are remarkable.

A previous commentary suggested that CGRP antagonists may be helpful in the fight against COVID-19 ${ }^{24}$ but, to the best of our knowledge, this is the first report on the reduced levels of the peptide in patients. CGRP belongs to a peptide family including also calcitonin, adrenomedullin, and amylin ${ }^{25}$. Interestingly, it has been published that the circulating levels of calcitonin ${ }^{26}$ and adrenomedullin ${ }^{27}$ are elevated in COVID-19 patients, probably as a consequence of widespread inflammation and/or blood vessel damage. No data are available for amylin. That CGRP goes in the opposite direction suggests a very specific regulation for this peptide.

The circulating levels of CGRP in patients which received chronic treatment with proton pump inhibitors were lower than in other patients. Although these treatments may slightly confound the final CGRP levels among the COVID-19 patients, we showed that COVID-19 patients not receiving these treatments had still significantly lower levels of the peptide. Even though no previous reports investigated the blood levels of CGRP in patients receiving these drugs, there are some animal models where exposure to omeprazole and other inhibitors significantly reduced the expression of CGRP in dorsal root ganglion neurons in the rat ${ }^{28}$. It has been shown that treatment with proton pump inhibitors is associated with higher odds of infection and with more severe clinical outcomes in COVID-19 patients ${ }^{29,30}$. The causes of these serious negative effects of the acid inhibitors are not presently known, but our results suggest that some of them may be mediated by a decrease in CGRP levels. 
medRxiv preprint doi: https://doi.org/10.1101/2020.10.01.20205088; this version posted October 2, 2020. The copyright holder for this

preprint (which was not certified by peer review) is the author/funder, who has granted medRxiv a license to display the preprint in It is made available under a CC-BY-ND 4.0 International license.

Ochoa-Callejero et al. 10

Previous studies have established the behavior of CGRP in the presence of viral infections. For instance, respiratory syncytial virus infections decrease CGRP expression in the lung, and treatment with CGRP abolished airway hyperresponsiveness

31. This is a behavior very similar to what we have observed in COVID-19 patients. The involvement of CGRP in reducing viral-induced hyperresponsiveness may be very helpful in the treatment of COVID-19 patients. In addition, it has been shown that CGRP may inhibit HIV-1 transmission ${ }^{32}$. Although the transmission mechanisms are different between these viruses, it might be interesting to test whether CGRP has any impact on SARS-CoV-2 life cycle.

The effects of CGRP as a potent vasodilator are well known ${ }^{10}$. A significant reduction in the levels of CGRP may result in widespread vasoconstriction in the lung, which may contribute to promoting vascular occlusion, one of the milestones of COVID-19 ${ }^{33}$. Another critical function of CGRP is its influence on the immune system. SARS-CoV-2 infection stimulates the production of prostaglandin $\mathrm{D}_{2}$ which, in turn, upregulates the ILC2 response, leading to sequestration of lymphocytes into the lung and peripheral lymphopenia ${ }^{34}$. CGRP is an inhibitor of ILC2 ${ }^{16}$, so we can infer that the lower levels of the peptide observed in COVID-19 patients would participate in worsening immune dysfunction and lymphopenia.

Our immunofluorescence study showed immunoreactivity for RAMP1 in the walls of the major blood vessels, bronchi, and bronchioli, as well as in the epithelium of conducting airways. To the best of our knowledge this is the first morphological description of RAMP1 immunoreactivity in the human lung, but it coincides very closely with the location of CGRP binding sites as studied by radioactive ligand binding 
medRxiv preprint doi: https://doi.org/10.1101/2020.10.01.20205088; this version posted October 2, 2020. The copyright holder for this preprint (which was not certified by peer review) is the author/funder, who has granted medRxiv a license to display the preprint in It is made available under a CC-BY-ND 4.0 International license.

Ochoa-Callejero et al.

12. COVID-19 samples had the same distribution of RAMP1 than non-COVID-19 lungs, with the exception that proliferating type II pneumocytes, which are found in many COVID-19 patients ${ }^{4}$, were also positive for RAMP1. In contrast, normal type II pneumocytes in non-COVID-19 samples did not express this receptor component. This result may explain the higher expression of RAMP1 that was found in COVID-19 lung samples using multiplex gene expression analysis ${ }^{6}$. The upregulation of the CGRP receptor may reflect a feed-back mechanism trying to compensate for the reduction in systemic CGRP levels. Also, the high expression of RAMP1 in proliferating type II pneumocytes may indicate an important implication of CGRP in the repair of the respiratory epithelium subsequent to damage caused by viral infection ${ }^{35}$.

All these evidences suggest that restoring CGRP levels may constitute a new intervention for COVID-19 patients. Although CGRP inhibitors have been more developed pharmacologically, due to their application in fighting migraines ${ }^{36}$, several experimental strategies have been proposed for elevating CGRP levels, with positive outcomes ${ }^{37-39}$. Application of these CGRP “donors” to COVID-19 patients may improve several critical manifestations of the disease, such as proper angiogenesis ${ }^{40}$, vasodilatation, bronchial epithelium repair, and immune system regulation. 
medRxiv preprint doi: https://doi.org/10.1101/2020.10.01.20205088; this version posted October 2, 2020. The copyright holder for this preprint (which was not certified by peer review) is the author/funder, who has granted medRxiv a license to display the preprint in It is made available under a CC-BY-ND 4.0 International license.

Ochoa-Callejero et al.

\section{References}

1. Machhi J, Herskovitz J, Senan AM et al. The Natural History, Pathobiology, and Clinical Manifestations of SARS-CoV-2 Infections. J Neuroimmune Pharmacol 2020;15:359-386.

2. Kouznetsov VV. COVID-19 treatment: Much research and testing, but far, few magic bullets against SARS-CoV-2 coronavirus. Eur J Med Chem 2020;203:112647.

3. Mullard A. COVID-19 vaccine development pipeline gears up. Lancet 2020;395:1751-1752.

4. Martines RB, Ritter JM, Matkovic E et al. Pathology and Pathogenesis of SARSCoV-2 Associated with Fatal Coronavirus Disease, United States. Emerg Infect Dis 2020;26:2005-2015.

5. Carsana L, Sonzogni A, Nasr A et al. Pulmonary post-mortem findings in a series of COVID-19 cases from northern Italy: a two-centre descriptive study. Lancet Infect Dis 2020;20:P1135-1140.

6. Ackermann M, Verleden SE, Kuehnel M et al. Pulmonary Vascular Endothelialitis, Thrombosis, and Angiogenesis in Covid-19. N Engl J Med 2020;383:120-128.

7. McLatchie LM, Fraser NJ, Main MJ et al. RAMPs regulate the transport and ligand specificity of the calcitonin-receptor-like receptor. Nature 1998;393:333-339.

8. Toda M, Suzuki T, Hosono K et al. Neuronal system-dependent facilitation of tumor angiogenesis and tumor growth by calcitonin gene-related peptide. Proc Natl Acad Sci U S A 2008;105:13550-13555.

9. Dakhama A, Larsen GL, Gelfand EW. Calcitonin gene-related peptide: role in airway homeostasis. Curr Opin Pharmacol 2004;4:215-220. 
medRxiv preprint doi: https://doi.org/10.1101/2020.10.01.20205088; this version posted October 2, 2020. The copyright holder for this preprint (which was not certified by peer review) is the author/funder, who has granted medRxiv a license to display the preprint in It is made available under a CC-BY-ND 4.0 International license.

Ochoa-Callejero et al. 13

10. Lo CCW, Moosavi SM, Bubb KJ. The Regulation of Pulmonary Vascular Tone by Neuropeptides and the Implications for Pulmonary Hypertension. Front Physiol 2018;9:1167.

11. Verastegui C, Prada OA, Fernandez-Vivero J, Romero A, de Castro JM. Calcitonin gene-related peptide immunoreactivity in adult mouse lung. Eur J Histochem 1997;41:119-126.

12. Mak JC, Barnes PJ. Autoradiographic localization of calcitonin gene-related peptide (CGRP) binding sites in human and guinea pig lung. Peptides 1988;9:957-963.

13. Zhou Y, Zhang M, Sun GY et al. Calcitonin gene-related peptide promotes the wound healing of human bronchial epithelial cells via PKC and MAPK pathways. Regul Pept 2013;184:22-29.

14. Kawanami Y, Morimoto Y, Kim H et al. Calcitonin gene-related peptide stimulates proliferation of alveolar epithelial cells. Respir Res 2009;10:8.

15. Li XW, Li XH, Du J, Li D, Li YJ, Hu CP. Calcitonin gene-related peptide downregulates bleomycin-induced pulmonary fibrosis. Can J Physiol Pharmacol 2016;94:1315-1324.

16. Xu H, Ding J, Porter CBM et al. Transcriptional Atlas of Intestinal Immune Cells Reveals that Neuropeptide alpha-CGRP Modulates Group 2 Innate Lymphoid Cell Responses. Immunity 2019;51:696-708.

17. Duan JX, Zhou Y, Zhou AY et al. Calcitonin gene-related peptide exerts antiinflammatory property through regulating murine macrophages polarization in vitro. Mol Immunol 2017;91:105-113.

18. Rochlitzer S, Veres TZ, Kuhne K et al. The neuropeptide calcitonin gene-related peptide affects allergic airway inflammation by modulating dendritic cell function. Clin Exp Allergy 2011;41:1609-1621. 
medRxiv preprint doi: https://doi.org/10.1101/2020.10.01.20205088; this version posted October 2, 2020. The copyright holder for this preprint (which was not certified by peer review) is the author/funder, who has granted medRxiv a license to display the preprint in It is made available under a CC-BY-ND 4.0 International license.

Ochoa-Callejero et al. 14

19. Wallrapp A, Burkett PR, Riesenfeld SJ et al. Calcitonin Gene-Related Peptide

Negatively Regulates Alarmin-Driven Type 2 Innate Lymphoid Cell Responses. Immunity 2019;51:709-723.

20. Baral P, Umans BD, Li L et al. Nociceptor sensory neurons suppress neutrophil and gammadelta $\mathrm{T}$ cell responses in bacterial lung infections and lethal pneumonia. Nat Med 2018;24:417-426.

21. Sui P, Wiesner DL, Xu J et al. Pulmonary neuroendocrine cells amplify allergic asthma responses. Science 2018;360(6393).

22. Li M, Wetzel-Strong SE, Hua X et al. Deficiency of RAMP1 attenuates antigeninduced airway hyperresponsiveness in mice. PLoS One 2014;9:e102356.

23. Tay MZ, Poh CM, Renia L, MacAry PA, Ng LFP. The trinity of COVID-19: immunity, inflammation and intervention. Nat Rev Immunol 2020;20:363-374.

24. Robertson CE. Could CGRP Antagonists Be Helpful in the Fight Against COVID19?. Headache 2020;60:1450-1452.

25. Lopez J, Martinez A. Cell and molecular biology of the multifunctional peptide, adrenomedullin. Int Rev Cytol 2002;221:1-92.

26. Lippi G, Plebani M. Procalcitonin in patients with severe coronavirus disease 2019 (COVID-19): A meta-analysis. Clin Chim Acta 2020;505:190-191.

27. Hupf J, Mustroph J, Hanses F, Evert K, Maier LS, Jungbauer CG. RNA-expression of adrenomedullin is increased in patients with severe COVID-19. Crit Care 2020;24:527.

28. Kondo T, Oshima T, Koseki J et al. Effect of rikkunshito on the expression of substance P and CGRP in dorsal root ganglion neurons and voluntary movement in rats with experimental reflux esophagitis. Neurogastroenterol Motil 2014;26:913921. 
medRxiv preprint doi: https://doi.org/10.1101/2020.10.01.20205088; this version posted October 2, 2020. The copyright holder for this preprint (which was not certified by peer review) is the author/funder, who has granted medRxiv a license to display the preprint in It is made available under a CC-BY-ND 4.0 International license.

Ochoa-Callejero et al. 15

29. Almario CV, Chey WD, Spiegel BMR. Increased Risk of COVID-19 Among Users of Proton Pump Inhibitors. Am J Gastroenterol 2020.

30. Lee SW, Ha EK, Yeniova AO et al. Severe clinical outcomes of COVID-19 associated with proton pump inhibitors: a nationwide cohort study with propensity score matching. Gut 2020.

31. Dakhama A, Park JW, Taube C et al. Alteration of airway neuropeptide expression and development of airway hyperresponsiveness following respiratory syncytial virus infection. Am J Physiol Lung Cell Mol Physiol 2005;288:L761-L770.

32. Ganor Y, Drillet-Dangeard AS, Bomsel M. Calcitonin gene-related peptide inhibits human immunodeficiency type 1 transmission by Langerhans cells via an autocrine/paracrine feedback mechanism. Acta Physiol (Oxf) 2015;213:432-441.

33. Leppkes M, Knopf J, Naschberger E et al. Vascular occlusion by neutrophil extracellular traps in COVID-19. EBioMedicine 2020;58:102925.

34. Gupta A, Chiang KC. Prostaglandin D2 a s a mediator of lymphopenia and a therapeutic target in COVID-19 disease. Med Hypotheses 2020;143:110122.

35. Mason RJ. Thoughts on the alveolar phase of COVID-19. Am J Physiol Lung Cell Mol Physiol 2020;319:L115-L120.

36. Wu D, Doods H, Arndt K, Schindler M. Development and potential of non-peptide antagonists for calcitonin-gene-related peptide (CGRP) receptors: evidence for CGRP receptor heterogeneity. Biochem Soc Trans 2002;30:468-473.

37. Aubdool AA, Thakore P, Argunhan F et al. A Novel alpha-Calcitonin Gene-Related Peptide Analogue Protects Against End-Organ Damage in Experimental Hypertension, Cardiac Hypertrophy, and Heart Failure. Circulation 2017;136:367383. 
medRxiv preprint doi: https://doi.org/10.1101/2020.10.01.20205088; this version posted October 2, 2020. The copyright holder for this preprint (which was not certified by peer review) is the author/funder, who has granted medRxiv a license to display the preprint in It is made available under a CC-BY-ND 4.0 International license

Ochoa-Callejero et al. 16

38. Kim BG, Park MK, Lee PH et al. Effects of nanoparticles on neuroinflammation in a mouse model of asthma. Respir Physiol Neurobiol 2020;271:103292.

39. Champion HC, Bivalacqua TJ, Toyoda K, Heistad DD, Hyman AL, Kadowitz PJ. In vivo gene transfer of prepro-calcitonin gene-related peptide to the lung attenuates chronic hypoxia-induced pulmonary hypertension in the mouse. Circulation 2000;101:923-930.

40. Teuwen LA, Geldhof V, Pasut A, Carmeliet P. COVID-19: the vasculature unleashed. Nat Rev Immunol 2020;20:389-391. 
medRxiv preprint doi: https://doi.org/10.1101/2020.10.01.20205088; this version posted October 2, 2020. The copyright holder for this preprint (which was not certified by peer review) is the author/funder, who has granted medRxiv a license to display the preprint in It is made available under a CC-BY-ND 4.0 International license

Table 1. Baseline characteristics of the study population

\begin{tabular}{|l|c|c|c|}
\hline & Controls & COVID-19 & $\boldsymbol{p}$ \\
\hline$n$ & 24 & 57 & \\
\hline Age, mean \pm SEM & $44.3 \pm 2.4$ & $58.3 \pm 2.5$ & $\mathbf{0 . 0 0 2}$ ף \\
\hline Sex (Male) & $9(37.5 \%)$ & $25(43.9 \%)$ & $0.63 \dagger$ \\
\hline CGRP (pg/ml), mean \pm SEM & $289.9 \pm 35.9$ & $105.7 \pm 7.0$ & $<\mathbf{0 . 0 0 1}$ \\
\hline
\end{tabular}

ๆ: U Mann-Whitney ; †: Fisher. Significant differences appear in bold case. 
medRxiv preprint doi: https://doi.org/10.1101/2020.10.01.20205088; this version posted October 2, 2020. The copyright holder for this preprint (which was not certified by peer review) is the author/funder, who has granted medRxiv a license to display the preprint in It is made available under a CC-BY-ND 4.0 International license

Ochoa-Callejero et al.

Table 2. Clinical characteristics of the COVID-19 patients included in the study

\begin{tabular}{|c|c|c|c|c|c|}
\hline & & Asymptomatic & $\begin{array}{l}\text { Hospital } \\
\text { ward }\end{array}$ & ICU & $p^{*}$ \\
\hline $\mathbf{n}$ & & 24 & 23 & 10 & \\
\hline $\begin{array}{l}\text { Age, mean } \pm \\
\text { SEM }\end{array}$ & & $44.3 \pm 1.9$ & $72.3 \pm 4.1$ & $\begin{array}{c}59.9 \pm \\
2.8\end{array}$ & $<0.001$ \\
\hline Sex (Male) & & $8(33.3 \%)$ & $9(39.1 \%)$ & $8(80 \%)$ & $0.19+$ \\
\hline \multicolumn{6}{|l|}{ Risks factors } \\
\hline & $\begin{array}{c}\text { Arterial } \\
\text { hypertension }\end{array}$ & $0(0 \%)$ & $13(56.5 \%)$ & $4(40 \%)$ & $<0.001 \dagger$ \\
\hline & Dyslipidemia & $0(0 \%)$ & $6(26.1 \%)$ & $2(20 \%)$ & $0.02+$ \\
\hline & Diabetes & $0(0 \%)$ & $4(17.4 \%)$ & $0(0 \%)$ & $0.13+$ \\
\hline & Obesity & $0(0 \%)$ & $2(8.7 \%)$ & $2(20 \%)$ & $0.13+$ \\
\hline & $\begin{array}{l}\text { Ischemic } \\
\text { cardiopathy }\end{array}$ & $0(0 \%)$ & 3 (13.0\%) & $1(10 \%)$ & $0.13+$ \\
\hline & Arrhythmia & 0 (0\%) & $3(13.0 \%)$ & $1(10 \%)$ & $0.13+$ \\
\hline & EPOC & $0(0 \%)$ & $4(17.4 \%)$ & $0(0 \%)$ & $0.13+$ \\
\hline \multicolumn{6}{|l|}{$\begin{array}{l}\text { Previous } \\
\text { treatment }\end{array}$} \\
\hline & ACE inhibitors & $0(0 \%)$ & $6(26.1 \%)$ & $3(30 \%)$ & $0.007+$ \\
\hline & Statins & $1(4.2 \%)$ & $5(21.7 \%)$ & $2(20 \%)$ & $0.12+$ \\
\hline & Antidiuretics & $0(0 \%)$ & $7(30.4 \%)$ & $2(20 \%)$ & $0.007+$ \\
\hline & Antidepressants & $0(0 \%)$ & $8(34.8 \%)$ & $1(10 \%)$ & $0.007+$ \\
\hline & $\mathrm{H}^{+}$pump inhibitors & $1(4.2 \%)$ & 9 (39.1\%) & $2(20 \%)$ & $0.008+$ \\
\hline & Beta blockers & $1(4.2 \%)$ & $3(13.0 \%)$ & $3(30 \%)$ & $0.22+$ \\
\hline & Anticoagulants & $0(0 \%)$ & $4(17.4 \%)$ & $0(0 \%)$ & $0.13+$ \\
\hline $\begin{array}{l}\text { CGRP }(\mathrm{pg} / \mathrm{ml}) \text {, } \\
\text { mean } \pm \text { SEM }\end{array}$ & & $100.9 \pm 7.6$ & $97.6 \pm 10.7$ & $\begin{array}{c}135.9 \pm \\
24.9\end{array}$ & 0.80 ๆ \\
\hline
\end{tabular}

* = p value comparing mild (Asymptomatic) vs severe (Hospital Ward and ICU) disease cases.

१: U Mann-Whitney ; †: Fisher. Significant differences appear in bold case. 
medRxiv preprint doi: https://doi.org/10.1101/2020.10.01.20205088; this version posted October 2, 2020. The copyright holder for this preprint (which was not certified by peer review) is the author/funder, who has granted medRxiv a license to display the preprint in It is made available under a CC-BY-ND 4.0 International license .

\section{Figures}

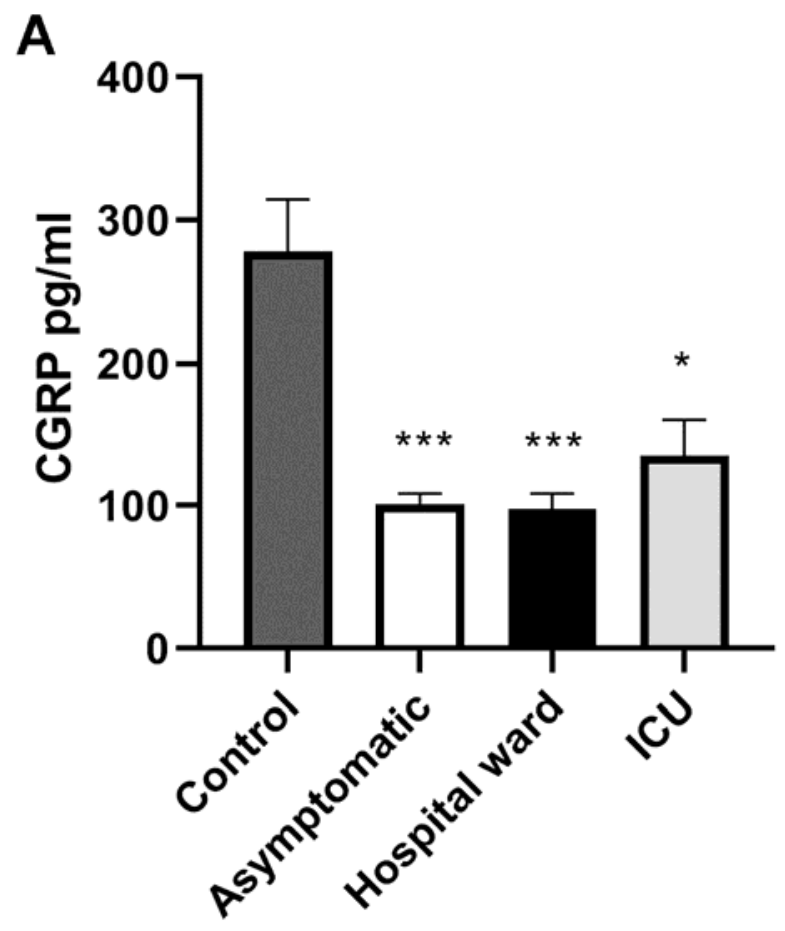

B

Figure 1. Serum CGRP levels as measured by ELISA. All COVID-19 positive patients (asymptomatic, hospital ward, or ICU) had significantly lower CGRP levels than healthy controls (A). Bars represent mean \pm standard error of the mean. Patients receiving chronic treatment with proton pump inhibitors had significantly lower CGRP levels than patients not receiving them (B). *: $\mathrm{p}<0.05 ; * *$ : $\mathrm{p}<0.01 ; * * *$ : $<<0.001$ compared to control. 

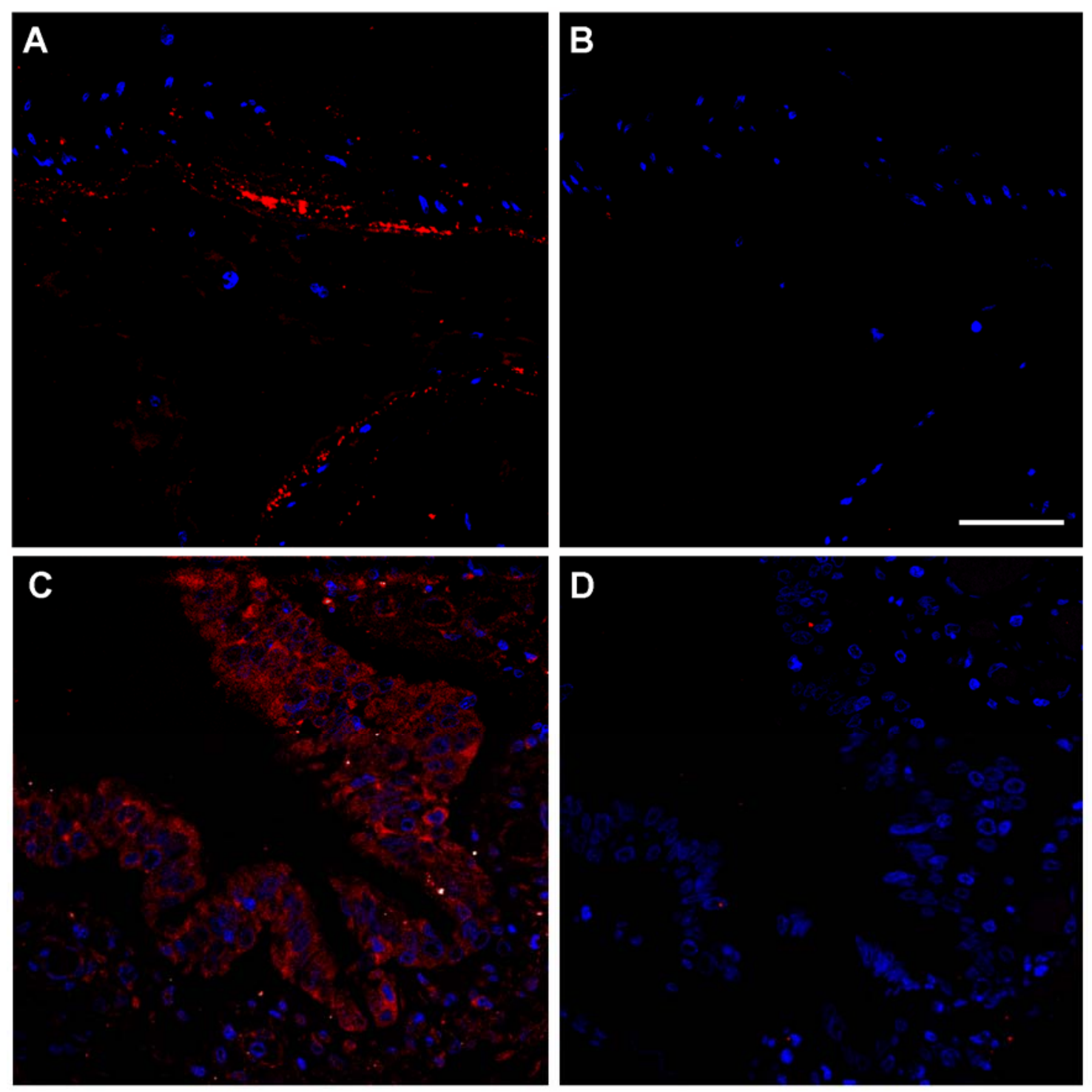

Figure 2. Representative confocal miscroscopy images of lung tissue sections from non-

COVID-19 autopsy specimens showing RAMP1 immunoreactivity (red) in the smooth muscle cells of an artery (A,B) and in the bronchiolar epithelium (C,D). Absence of the primary antibody (B,D) was used as a negative control. Cell nuclei were counterstained with DAPI (blue). Scale bar $=50 \mu \mathrm{m}$. 
medRxiv preprint doi: https://doi.org/10.1101/2020.10.01.20205088; this version posted October 2, 2020. The copyright holder for this preprint (which was not certified by peer review) is the author/funder, who has granted medRxiv a license to display the preprint in It is made available under a CC-BY-ND 4.0 International license.

Ochoa-Callejero et al.
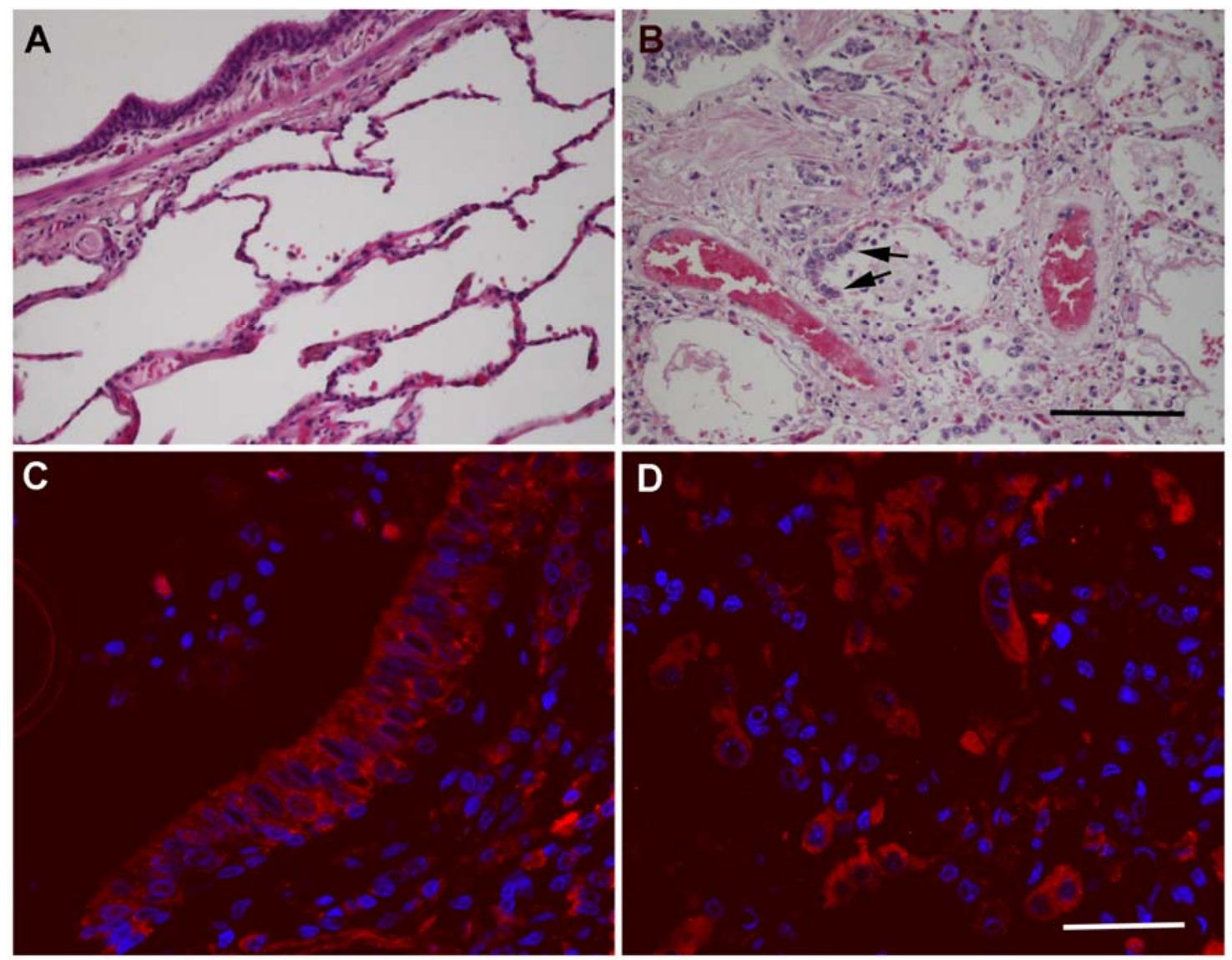

Figure 3. Representative microphotographs of the lung of non-COVID-19 (A) and of SARS-CoV-2-positive samples (B-D). Hematoxylin-eosin stained sections (A,B) show clear histological changes caused by SARS-CoV-2 infection, including proliferation of type II pneumocytes (arrows in B). Immunofluorescence for RAMP1 shows the distribution of this receptor component in the bronchiolar epithelium (C) and the hyperplastic type II pneumocytes (D) in SARS-CoV-2 samples. Scale bar for A and B = $200 \mu \mathrm{m}$. Scale bar for C and D = 50 $\mu \mathrm{m}$. 